\title{
The ensemble scenarios projecting runoff changes in large Russian river basins in the 21 st century
}

\author{
ALEXANDER G. GEORGIADI, NIKOLAI I. KORONKEVICH, \\ IRINA P. MILYUKOVA \& ELENA A. BARABANOVA \\ Institute of Geography, Russian Academy of Sciences, Staromonetny lane, 29, 119017 Moscow, Russia \\ galex50@gmail.com
}

\begin{abstract}
An approach is presented for carrying out a long-term projection of river runoff changes in large Russian river basins in the first three decades of the 21 st century. These changes may be caused by climate warming and socio-economic factors. The approach utilizes a method for scenario estimation of runoff changes with a range of possible climate warming effects. This range is chosen by generalizing calculation results obtained by using an ensemble of global climate models for two contrasting scenarios (A2 and B1) of globally-averaged air temperature rises. The approach also utilizes a method for alternative scenario estimation for water consumption as related to socio-economic changes. The estimates show that the expected runoff changes in the first third of this century due to climate warming scenarios can compensate the runoff decrease caused by the realization of some of the scenarios for socio-economic changes in the Volga River basin. The same compensation does not occur in the Don River basin, where negative effects are expected for the regional ecology.
\end{abstract}

Key words scenarios of river runoff changes; global climate warming; large river basins

\section{INTRODUCTION}

Global climate warming and socio-economic changes are the leading factors in determining the future state of large river basin water systems which play an important role in the economic development of Russia. For this reason, it is necessary to generate integrated scenarios of river runoff changes within the large river basins, which would take into account the long-term probable changes of the two factors. Such scenarios should provide a basis for an ecologically safe management of water systems in the future.

According to the results of the previous investigations, one-scenario forecasts, let alone longterm forecasts, do not generally provide a comprehensive picture of future conditions. This is particularly true for the rapidly changing economic and water management activities. Therefore, it seems important to predict the future situation based on different scenarios of its development. This is the reason why so much attention is given to the development of long-term scenario forecasting for the hydrological effects of global climate change and the water management system transformation in large Russian river basins.

In recent years, the authors have developed a methodology for long-term scenario projections of river runoff changes, which includes a water balance model, methods for the assimilation of global climate warming scenarios, methods for the scenario estimates of the water management system transformation, and GIS technologies.

\section{RESEARCH METHODOLOGY}

The approach taken to create a long-term scenario projection of river runoff changes in large Russian river basins in the first third of the 21st century includes two methods: (1) a method generating scenario estimations of runoff changes for a range of probable climatic warming scenarios based on the generalization of calculated results obtained by using an ensemble of global climate models, and (2) a method for alternative scenario estimations for the water management system transformation caused by socio-economic changes and their impact on the river runoff.

\section{Monthly water budget model}

The model and its application to the largest river basins of the Russian plain are considered in detail in the following publications: Georgiadi and Milyukova $(2002,2010)$ and Georgiadi et al. (2011). 
This model can be categorized under macro-scale hydrological models that have been actively developed in recent years (Willmott et al. 1985, WATCH 2008). The model is based on the conservation equation for the long-term monthly average water balance of river watersheds. The model simulates the following processes: infiltration and moisture accumulation in the soil; evaporation (based on a modified Thornthwhaite's method (Willmott et al. 1985)); water accumulation in the snow cover and snow melting (based on V.D. Komarov's method, Manual on Hydrological Forecasts 1989); movement of the freezing front calculated from a simplified solution for classical single-front Stefan problem (Belchikov and Koren 1979; Pavlov 1979); formation of surface, subsurface and groundwater flow in the rivers and full river runoff. In the monthly water balance model, the changes in the river runoff and other water balance elements are estimated in the cells of a regular grid, which facilitates the coupling of the model and climate model simulations.

The range of probable climatic changes, which is estimated by calculating deviations of climatic elements from their recent values, is used as a climatic scenario. The calculations are made for the two scenarios using the most (A2) and least (B1) intensive rises of globally averaged air temperatures. Calculation results obtained by using 10 global climate models are employed. These were included in the IPCC program for their experiment "20C3M-20th Century Climate in Coupled Models". The climatic models were chosen from more than 20 climatic models by comparing the present-day observed climatic conditions with the simulated ones (Georgiadi et al. 2011). The range of scenario deviations of mean monthly air temperatures and precipitation totals is determined for each scenario ensemble mentioned by averaging the calculated results obtained from each of the climate models chosen.

\section{Method for alternative scenario estimations for water management system transformation}

The methodology of estimating the impact of socio-economic changes on river runoff resources (Koronkevich 1990, Georgiadi et al. 2009, 2011) is based on the assumptions of different rates of socio-economic development of a country and its regions and on the scenarios built around using different levels of water consumption and the water system protection technologies in place.

Major water consumers (household and industrial water use, irrigation, and rural water supply) are taken into account. Scenarios of household water use changes are recognized with regard to urban and rural population dynamics.

Scenarios of accelerated, moderate and minimum socio-economic development are considered. The scenarios are based on the current specific level of water consumption and its maximum, average and minimum decrease. Changes in storage evaporation rates and land treatment effects are also taken into account.

It is essential to understand that in the past decades, the water consumption dynamics in the Volga and Don river basins are in many respects close to that which was typical for Russia as a whole (Fig. 1(a),(b)). This makes it possible to use economic and water consumption changes recorded/predicted for the whole of Russia when working out basin scenarios. Along with this, the natural and economic peculiarities of individual basins are to be taken into account in prediction scenarios as well. The general algorithm for the method behind alternative scenario estimations for the water management system transformation takes place in two stages: pre-prediction and prediction.

The pre-prediction stage includes the following steps: general orientation of the method development; analysis of natural conditions and space-time regularities of water resources distribution and water resources quality; analysis of economic activity and its impact on water systems; analysis of water system state dynamics; and selection of operating units.

The prediction stage consists of the following steps: consideration of the expected natural hydrological and climatic situation; consideration of predicted population and economic development; estimation of probable changes in water use technology; consideration of the aggregate of anthropogenic and natural climatic factors; and scenario verification from water economy balances. 

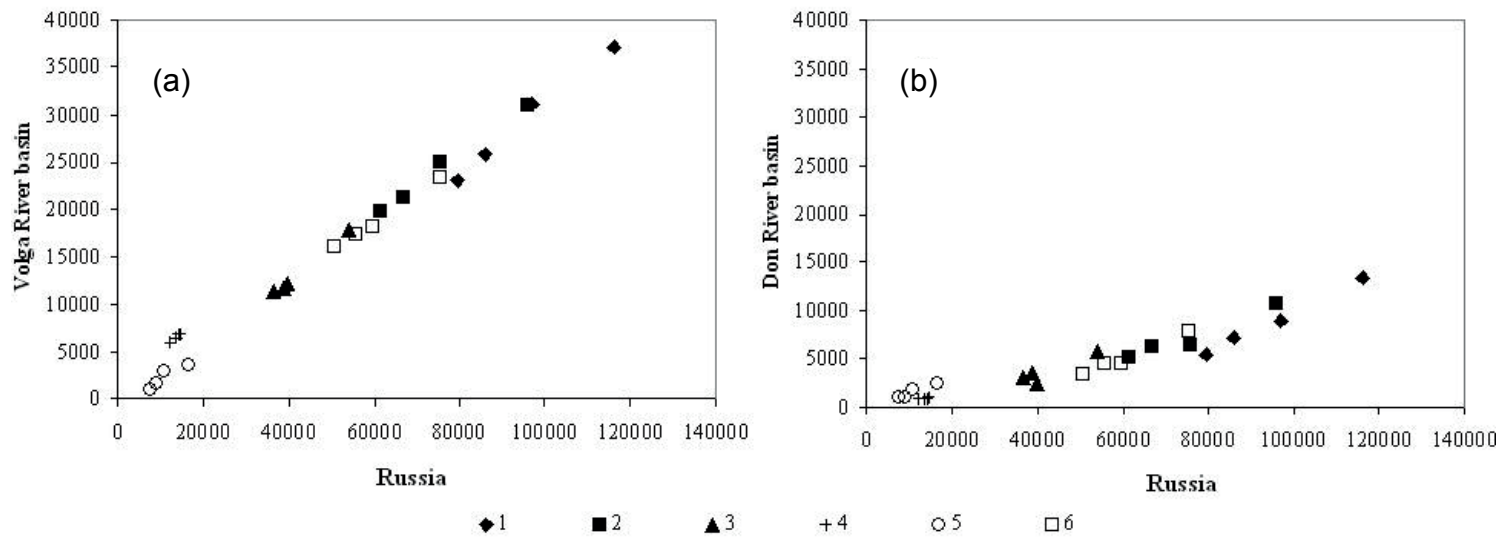

Fig. 1 Water consumption indices in Russia as related to those in the Volga (a) and Don (b) basins (in $\mathrm{km}^{3} /$ year) in 1990, 1995, 2000 and 2005. (1) the total water amount abstracted; (2) the total water amount used; (3) the water amount used to meet production needs; (4) the water amount used for domestic water supply; (5) the water amount used for irrigation; and (6) the total sewage amount discharged.

Estimates of future anthropogenic impacts on water resources for the years 2025-2030 are based on three scenarios for population change (average, maximum and minimum), three options for economic development (inertia, energy and resource-based, and innovative) and four scenarios of specific water consumption change (reserved by the basic levels in 2000-2005, average, maximum and minimum reduction). According to the official statistical forecast, the 1.05-1.15 times population decline is expected to be reached by 2025-2030. The Ministry of Economic Development of The Russian Federation gives the following economic growth rates of economic development for the same period - in industry $3-5 \%$ per year increase, $2-4 \%$ in the sectors of agriculture, $1-3 \%$ in other industries (Kuzyk and Yakovets 2006).

Possible improvement in the water use technology provides an opportunity to plan for a $1.2-5$ times reduction in waste delivery (Laskorin et al. 1981, Demin 2005). There is a $10 \%$ per capita decline expected in domestic water use according to the scenario of the average specific water consumption changes, $20 \%$ - according to the maximum changes and $5 \%$ - according to the minimum changes. Industrial water use in the Volga and Don basins is projected to show a 1.7 times reduction according to the scenario of maximum specific water consumption changes, a 1.5 times reduction in the medium scenario and a 1.2 times reduction in the minimum scenario, which is slightly lower than the average reduction for Russia as a whole, taking into account possible waterintensive industry distribution in the areas rich in water resources. In agriculture, the consumption of water for irrigation will decrease by 1.1-1.5 times. This reduction is less than the average for Russia at the present day, where for example in the Volga and Don basins sprinkler irrigation is used for large areas as it is a more economical form of irrigation compared to contour ditch irrigation, prevailing in regions like northern Caucasia.

\section{HYDROCLIMATIC CHANGES IN THE FIRST THREE DECADES OF THE 21st CENTURY}

\section{Specific features of air temperature and atmospheric precipitation changes}

In the first three decades of the 21st century the mean annual air temperature in the Volga and Don river basins is expected to rise by $1.4-2^{\circ} \mathrm{C}$ and $1.3-1.5^{\circ} \mathrm{C}$, respectively (the first value is appropriate to the $\mathrm{A} 2$ scenario and the second value, to the $\mathrm{B} 1$ scenario). According to the scenarios, the mean annual atmospheric precipitation will increase in the Volga basin by $32 \mathrm{~mm}$ (the A2 scenario) and by $24 \mathrm{~mm}$ (the B1 scenario) and in the Don basin by 10 and $13 \mathrm{~mm}$, respectively, which is within the limits of 5\% for the Volga and 2\% for the Don as it relates to its recent values. Intra-annual distributions of air temperature and atmospheric precipitation scenario changes in the Don basin were quite similar for the A2 and B1 scenarios, however the figures for the Volga basin were substantially different. 


\section{Main trends for river runoff changes}

Considering the previously mentioned scenarios for climate changes, the mean annual Volga River runoff is expected to change slightly in the $\mathrm{B} 1$ scenario, but can increase by more than $10 \%$ under the A2 scenario, whereas the annual runoff in the Don basin remains almost unchanged under both the $\mathrm{A} 2$ and $\mathrm{B} 1$ scenarios (Fig. 2).

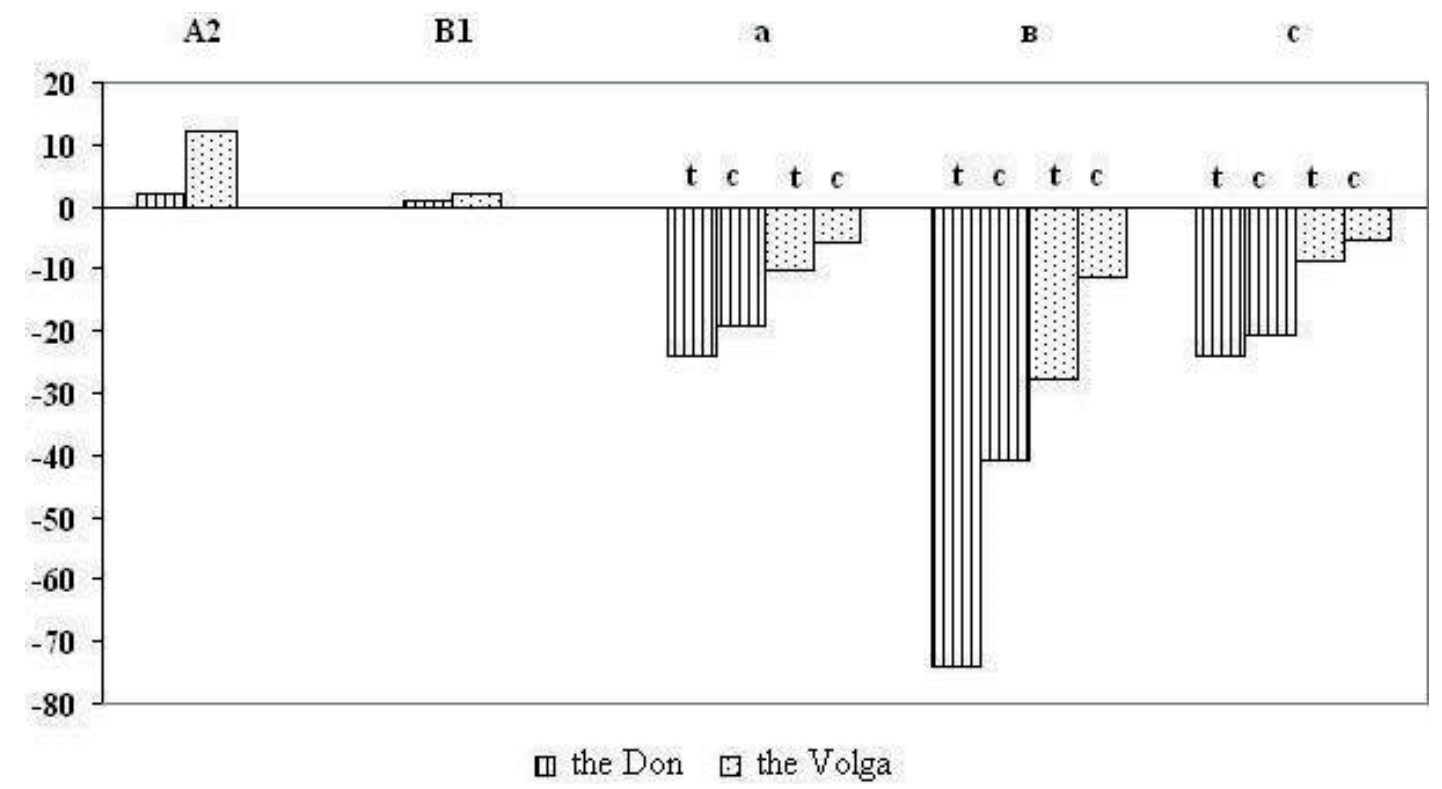

Fig. 2 Observed and expected future (2025-2030) water abstraction in the Don and Volga basins, and the projected change in their mean annual runoff in the first three decades of the 21 st century with contrasting $\mathrm{A} 2$ and B1 scenarios of global climate warming (as a percentage of the mean annual runoff). $\mathbf{t}-$ total water withdrawal, $\mathbf{c}$ - consumptive water use

The response of the intra-annual runoff structure to scenario climate changes is also quite different for the Volga and Don basins. A flattening-out of the flood wave can be expected for the Don River, while in contrast, on the Volga River in the month of the highest runoff during a flood there may be a runoff increase, whereas the runoff of the next month can decrease (Fig. 3). The winter runoff can increase both on the Volga and on the Don, however the summer-autumn runoff on the Volga may be lower than the recent runoff and on the Don it may be higher.

\section{SCENARIO CHANGES IN THE CHARACTERISTICS OF WATER MANAGEMENT SYSTEMS}

It is shown that the further retaining of the existing specific water consumption rates in the Volga and, in particular, the Don basins is inadmissible since under any scenario, this imposes an excessive load on the water elements of the environment, mainly of the river runoff.

With the most favourable scenario of economic development and the current specific water consumption retained, water abstraction, as compared to the existing situation (Fig. 2(a)), can increase by 2.7 to 3 times and reach 28 and $74 \%$ of the mean annual runoff in the Volga and Don basins, respectively, (Fig. 2(b)), which is inadmissible in respect to water economy and ecology. However, a close to current level of water abstraction can be retained (Fig. 2(c)) with specific water consumption reduced by a factor of 1.5-1.6 and moderate rates of economic development.

Reduction in specific water consumption based on the known technological solutions, primarily those intended to avoid non-productive water losses, will allow a substantial decrease in major water consumption indices. Moreover, with one of the scenarios of economic development and maximum possible introduction of new technology, this will allow the anthropogenic load on water resources to be lower than or approximately equal to current levels, with a significantly higher standard of living attained. 

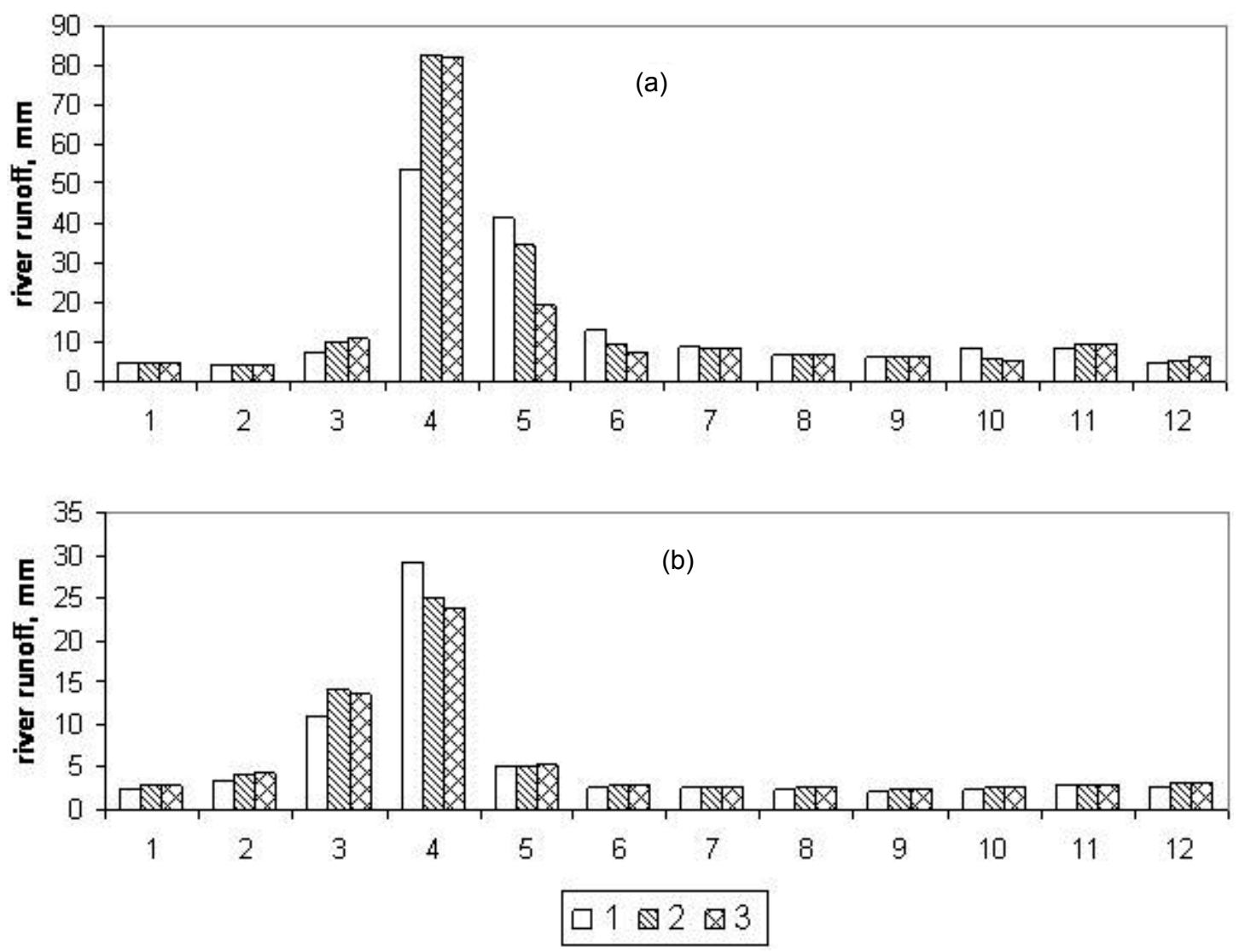

Fig. 3 Hydrographs of monthly runoff depths: observed runoff (1) and runoff under climatic A2 (2) and B1 (3) scenarios averaged over regular grid cells for the Volga (a) and Don (b) river basins.

\section{CONCLUSION}

The proposed ensemble approach to the long-term scenario projecting of runoff changes in large river basins, related to the socio-economic transformation and global climate warming, allows for the estimation of a range of runoff changes in the Volga and Don basins that can be expected in the first three decades of the 21 st century.

With the most favourable scenario of economic development and the current specific water consumption retained, water abstraction, as compared to its current level, can increase by as much as three times and reach a critical level, which will have an adverse effect on the water management system and the environment. However, the current water abstraction levels can be retained with specific water consumption reduced by a factor of 1.5 and with moderate rates of economic development. By recognizing global climate warming scenarios, the mean annual Volga runoff can increase, which, to a certain extent, offsets the negative impacts of water abstraction growth. Meanwhile the same compensation does not occur in the Don River basin, where negative effects are expected to take their toll on regional ecology.

This study was supported by The Russian Foundation on Basic Research grants 11-05-01057, 13-05-41437.

\section{REFERENCES}

Belchikov, V. and Koren, V. (1979) Model of snow melting and rain runoff formation for forest watersheds. Proc. of Hydrometeocenter of the USSR 218, 3-21 (in Russian).

Demin A.P. (2005) Dynamics of water use efficiency in the Russian regions. Newsletter "The use and protection of natural resources in Russia" 2, 48-57 (in Russian).

Georgiadi, A. and Milyukova, I. (2006) Possible river runoff changes in the largest river basins of the Russian Plain in the 21st century. Water Management System of Russia 1, 62-77 (in Russian).

Georgiadi, A. and Milyukova, I. (2002) Possible scales of hydrological changes in the Volga river basin during anthropogenic climate warming. Meteoro. and Hydrol. 2, $72-79$ (in Russian). 
Georgiadi, A., et al. (2010) Approaches to scenario estimation of water resources variations in large river basins. Proc. of Third Rus. Sci. Conf. ART Publ. House, 355-357. (in Russian).

Georgiadi, A., et al. (2009) Integrated scenarios of long-term river runoff changes within large river basins in the 21 st century. In: The Role of Hydrology in Water Resources Management (ed. by H. J. Liebscher et al.), 45-51. IAHS Publ. 327. IAHS Press, Wallingford, UK.

Georgiadi, A., et al. (2011) Scenario Estimation of Probable River Runoff Changes in the Largest Russian River Basins. Part I: The Lena River Basin. Max Press. (in Russian).

Georgiadi, A., Milyukova, I. and Kashutina, E. (2010) Response of river runoff in the cryolithic zone of Eastern Siberia (Lena River basin) to future climate warming. Chapter 10. (ed. by H. Balzter) Environmental change in Siberia: Earth observation, field studies and modelling. Advances in Global Change Research 40, doi 10.1007/978-90-481-8641-9_10, Springer Science+Business Media B.V., 157-169.

Koronkevich, N. (1990) Water Balance of the Russian Plain and its Anthropogenic Changes. Nauka, Moscow. (in Russian).

Kuzyk B. N. and Yakovets U. V. (2006) Integral Macroeconomic Forecast of Innovation and Technology and the Structural Dynamics of the Economy of Russia until 2030. Moscow, Institute for Economic Strategies (in Russian).

Laskorin B.N., et al. (1981) Major Problems of Nonwaste Production. Moscow, Stroyizdat (in Russian).

Manual on Hydrological Forecasts (1989) Issue 1: Long-term Forecasts of Water Regime of Rivers, Lakes and Water Reservoirs Gidrometeoizdat, Leningrad (in Russian).

Pavlov, A. V. (1979) Thermophysics of Landscapes. Nauka, Novosibirsk, Russia (in Russian).

WATCH (Water and Global Changes). (2008) Technical Report No.1, 1-19.

Willmott, C., Rowe, C. and Mintz, Y. (1985) Climatology of the terrestrial seasonal water cycle. J. Climatology 5, 589-606. 